The snowdrift effect on snow deposition

\title{
The snowdrift effect on snow deposition: insights from a comparison of a snow pit profile and meteorological observations
}

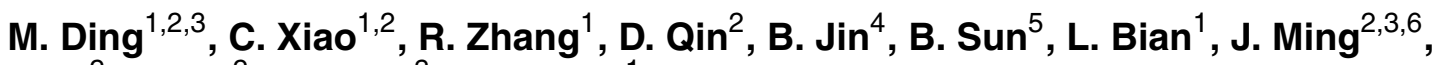
C. $\mathrm{Li}^{2}, \mathrm{~A} . \mathrm{Xie}^{2}$, W. Yang ${ }^{3}$, and Y. $\mathrm{Ma}^{1}$

${ }^{1}$ Institute of Climate System, Chinese Academy of Meteorological Sciences, Beijing 100081 , China

${ }^{2}$ State Key Laboratory of Cryospheric Sciences, Cold and Arid Regions Environmental and Engineering Research Institute, Chinese Academy of Sciences, Lanzhou 730000, China

${ }^{3}$ Snow-Ice-Aerosol Analyzing Laboratory, Beijing 100012, China

${ }^{4}$ Chinese Arctic and Antarctic Administration, Beijing 100860, China

${ }^{5}$ Polar research institute of China, Shanghai 200136, China

${ }^{6}$ National Climate Center, China Meteorological Administration, Beijing 100081, China

Received: 1 March 2013 - Accepted: 24 March - Published: 3 April 2013

Correspondence to: M. Ding (dingminghu@ @ams.cma.gov.cn)

Published by Copernicus Publications on behalf of the European Geosciences Union.
}

M. Ding et al.

Title Page 


\section{Abstract}

A high-frequency and precise ultrasonic sounder was used to record precipitated/deposited snow and drift events over a 3 yr period (17 January 2005 to 4 January 2008) at the Eagle automatic weather station (AWS) site. Through a comparison 5 of the meteorological data with snow pit chemical/isotopic dating results, the snowdrift process effect during snow accumulation was assessed. We believe that ice/firn cores are the most important proxies of climate and the environment because of their high resolution and their preservation of historical greenhouse gas levels, although their limitations and measurement uncertainties must be taken into account, due to the event-driven snow dominates the snow deposition. This study found a difference between two dating results of up to 12 months for a $\sim 95 \mathrm{~cm}$ snow pit, where the annual snow accumulation rate is $30.3 \mathrm{~cm}$. A weakness is also indicated when simulating the surface mass balance in Antarctica.

\section{Introduction}

15 Ice cores, loess, and stalagmites are the most important proxies for paleoclimate studies. Among them, ice cores have become increasingly more attractive due to their high temporal resolution, the variety of environmental information they provide, and most importantly, the historical greenhouse gas record that can be extracted from them. Since the last century, glaciologists have conducted numerous ice core studies on Antarctica, Greenland, and mountain glaciers. These studies include the Vostok Ice Core Project (Ekaykin et al., 2010) and the EPICA Dome C project (EPICA Community Members, 2004) in Antarctica, the NEEM international project and the GNIP project in Greenland (Ren et al., 2008), and the Guliya ice core project on the Tibetan Plateau (Wu et al., 2004).

25 Different from loess or stalagmites, the sediment (precipitation) on glaciers and ice sheets primarily comes from the ocean surface in the form of snow, and sonw is
The snowdrift effect on snow deposition

M. Ding et al.

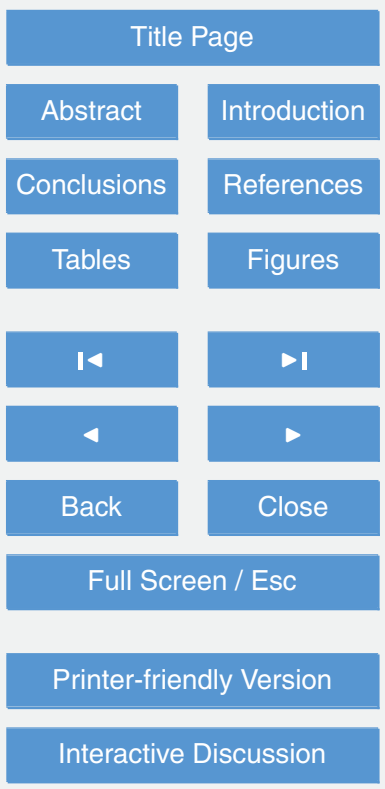


transported by the wind before it is permanently added to the underlying snow cover (Groot Zwaaftink et al., 2013). Furthermore, the post-depositional process occurs after/during snow events (Frezzotti et al., 2002; Esien et al., 2008), influenced by thermodynamics (during firnification) and wind (snowdrift) (Fierz and Lehning, 2001), which 5 may lead to a misunderstanding of climate records.

Many studies have discussed the post depositional effect by wind. Such as: Watanabe (1978) described the deposition-erosion processes at Mizuho Plateau; Frezzotti et al. (2007) estimated the role of SPWD in the snow erosion near Talos Dome; Petit et al. (1982) suggested the local erosion could be on the same order of magnitude as 10 precipitation; Groot Zwaaftink et al. (2013) simulated the the event-driven deposition of snow, and found that the precipitation is not the driving force behind non-temporary snow height changes. However, it still could not give an accurate estimation of post depositional processes, because but not only drifting and blowing snow events are hard to observe.

15 As part of the ongoing deep ice core project in Dome A, Antarctica, the 21st CHINARE drilled a $109.91 \mathrm{~m}$ shallow core and tried to obtain the primarily environmental characteristics of the Dome A area. However, it was quite surprising to learn that the two dating results of the core by Jiang et al. (2012) and Li et al. (2012) differed significantly. The former study obtained a $2840 \mathrm{yr}$ record for the top $100.42 \mathrm{~m}$ and the latter a $4115 \pm 150 \mathrm{yr}$ record for the whole core, a difference of up to $1275 \mathrm{yr}$ (a misinterpretation rate of $31 \%$ to $45 \%$ ). One of the most likely reasons for this discrepancy is disturbance of the proxy by post-depositional processes.

How large, then, is the influence of the post-depositional process? Could it disturb the seasonal or even annual signal? Here, we will present a case study and attempt to explore the snowdrift process by sampling the snow profile under the ultrasonic sounder of an automatic weather station (AWS).

\section{TCD}

, 1415-1439, 2013

The snowdrift effect on snow deposition

M. Ding et al.

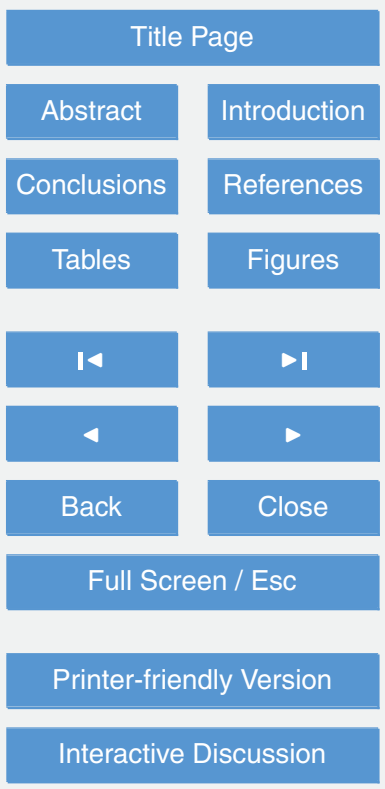




\section{Location and method}

Since 1997, the Chinese National Antarctic Research Expedition (CHINARE) began its traverse to the inland Antarctic area and installed 5 AWSs along the Zhongshan Station to Dome A route (Fig. 1). The Eagle AWS $\left(76^{\circ} 25^{\prime} \mathrm{S}, 77^{\circ} 01^{\prime} \mathrm{E}\right.$; $2852 \mathrm{~m}$ a.s.I.) 5 was deployed on 27 January 2005, as part of a cooperative effort between China and Australia, when the 21st CHINARE first arrived at Dome A. Its distance to the coast is nearly $806 \mathrm{~km}$. Eagle was designed by the Australian Antarctic Division and calibrated before being placed in the field, and it has made continuous observations since its deployment. Eagle measures the air temperature (1, 2, $4 \mathrm{~m})$, wind speed $(1,2,4 \mathrm{~m})$, wind direction $(4 \mathrm{~m})$, atmospheric pressure $(4 \mathrm{~m})$, global radiation $(4 \mathrm{~m})$ and firn temperature $(-0.1 \mathrm{~m},-1 \mathrm{~m},-3 \mathrm{~m},-10 \mathrm{~m})$. The snow surface height (SSH) is also observed by an ultrasonic sounder (Fig. 2). Table 1 lists the major sensors and their resolutions. The sampling frequency is set as 24 times per day, and the data are transmitted in real time through the Data Collection System of the ARGOS supporting satellite. These sensors 15 make it possible to correct for the observation errors due to wind and air temperature (Eisen et al., 2008). In Antarctica, there are approximately 30 AWSs of this type (http://aws.acecrc.org.au/datapage.html), and they have been proven to have a high credibility (e.g. Allison et al., 1993, 1998; Ma et al., 2010).

On 4 January 2008, 50 snow samples were collected at a $\sim 3 \mathrm{~cm}$ interval from a $165.9 \mathrm{~cm}$ snow pit profile at Eagle, and the density profile was measured using the tube method (Ding et al., 2011). The stable oxygen isotopic composition and major ions were analysed using a stable isotope ratio mass spectrometer (Finnigan MAT252) and an Ion Chromatography System (Dionex ICS-3000) at the State Key Laboratory of Cryospheric Sciences, Chinese Academy of Sciences. All procedures, such as prepa25 ration, fieldwork, sealed transportation, and analytical testing, were carried out very carefully to prevent adverse environmental impacts and contamination. The oxygen isotopic composition was reported in terms of the standard $\delta^{18} \mathrm{O}$ value, representing
The snowdrift effect on snow deposition

M. Ding et al.

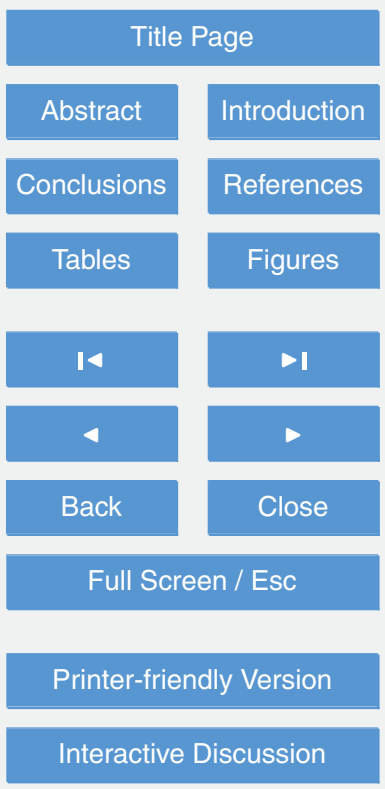


the difference in the ${ }^{18} \mathrm{O} /{ }^{16} \mathrm{O}$ ratios between the sample and the standard V-SMOW. The accuracy was estimated as $\pm 0.15 \%$.

As Fig. 3 shows, the $\delta$ value ranges from $-40.30 \%$ o to $-52.75 \%$, with an average of $-47.86 \%$, and the standard deviation is $3.42 \%$. In contrast to previous studies (Ding

5 et al., 2010; Xiao et al., 2012), this result captures the correct level of the local stable oxygen isotopic composition.

\section{Discussion}

\subsection{The climatology of Eagle}

The Eagle AWS is located within the "Extremely Flat Area" of inland Antarctica, with 10 a hard surface crust (Ding et al., 2011) and an average slope of $\sim 3.40 \mathrm{~m} \mathrm{~km}^{-1}$ (calculated from the digital elevation model developed by the US National Snow and Ice Data Center). Its prevailing aspect is northwards at the eastern side of the Lambert Glacier Basin, but the prevailing wind direction is northeast (56.3\%, see Fig. 4). The annual average wind speed is $4.17 \mathrm{~m} \mathrm{~s}^{-1}$ because of the atmospheric circumfluence (Allison et al., 1993; 1998; Zhou et al., 2009; Ma et al., 2010). Although the ice divide of east Antarctica starts to increase in this area, katabatic wind has almost no influence, as the observations show. The observed annual average temperature, relative humidity, air pressure, and snow accumulation are $40.80^{\circ} \mathrm{C}, 53.67 \%, 683.52 \mathrm{hPa}$, and $30.33 \mathrm{~cm}$, respectively (Ma et al., 2010).

20 According to the AWS records, only $\sim 95 \mathrm{~cm}$ of snow accumulated during January 2005 to January 2007 , so this paper will only describe the top $100 \mathrm{~cm}$ of the $\delta^{18} \mathrm{O}$ vertical profile of the Eagle snow pit.

The snowdrift effect on snow deposition

M. Ding et al.

Title Page

Abstract Introduction

Conclusions References

Tables Figures

I4

\section{Full Screen / Esc}

Printer-friendly Version

Interactive Discussion 


\subsection{The post-depositional process}

The post-depositional processes include densification, firnification, snowdrift, sublimation, and ice stretching processes etc. In the densification process, as the density of snow stratification increases with the new precipitation deposits on the snow surface

5 (e.g. Gow, 1969; Goodwin, 1991), the increase of the snow height is suppressed at the same time. Our measurements show that the density gradient along the Eagle snow pit stays relatively stable (Fig. 3), partly due to the wind crust structure (Fig. 2) by a high annual mean wind directional constancy of 0.91 (Fig. 4). In the firnification process, when the densification process occurs, physical properties such as particle size and transmittance will change until the snow becomes ice (e.g. Paterson, 1994; Williams et al., 2000; Frezzoti et al., 2004), it has no direct connection with snow height. Although it is known that sublimation in Antarctica is not negligible (e.g. Stearns and Weidner, 1993; Bintanja, 1998a; Gallée, 1998; Gallée et al., 2001; van den Broeke et al., 2005) and that wind-driven sublimation processes (controlled by the surface slope along the prevailing wind direction, SPWD) have an enormous impact (up to $85 \%$ of snow precipitation) on SMB and are significant in terms of past, present, and future SMB evaluations in the katabatic area (Frezzoti et al., 2004, 2007), sublimation can still be recorded by an ultrasonic sounder (Scarchilli et al., 2008, 2010). It has been proved that the net mass loss by sublimation on the Antarctic surface is no more than $5 \%$ of the precipitation (Qin et al., 2001), so we combined this process with the snowdrift process in this study. Ice stretching happens deep inside the ice sheet (e.g. Rignot et al., 2008; Anschutz et al., 2011). In the snowdrift process, the surface snow can be transported from the original location and re-deposited at a new location as a result of wind (Groot Zwaaftink et al., 2013). This effect is regularly neglected in studies on environmental 25 records.

However, the estimations of the snowdrift shows that it can lead to significant layer losses during the strong wind season (e.g. Bintanja, 2000; Frezzotti et al., 2002; Scarchilli et al., 2011; Groot Zwaaftink et al., 2013). Sublimation could also be
The snowdrift effect on snow deposition

M. Ding et al.

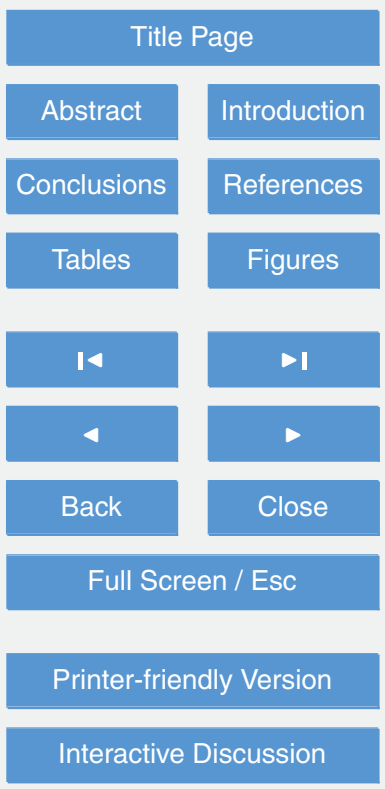

Interactive Discussion 
accelerated by wind (e.g. Smith 1995; Gallée, 1998; Bintanja 1998a; 2001; Gallée et al., 2013), with a maximum value of $0.1-0.2 \mathrm{mmd}^{-1}$ around the Talos Dome (Scarchilli et al., 2008). A few studies on snowdrift have been carried out over polar ice sheets, and some empirical functions and models have been established (e.g. Pomeroy and 5 Jones, 1996; McConnell et al., 1997; Bintanja, 1998a, b; Mann et al., 2000; Scarchilli et al., 2010; Groot Zwaaftink et al., 2013), but almost all of these studies focused on mass loss processes by wind and did not give an overall estimation of the snowdrift process, especially the misinterpretation of the snow layer. Therefore, we will provide a case study in the next section and attempt to determine how large the influence of the snowdrift process is on the snow depositional layer.

\subsection{Dating the snow pit}

First, we dated the snow pit by marine aerosols and $\delta^{18} \mathrm{O}$ cycles (Fig. 5) (Legrand and Mayewski, 1997). The results show good seasonal variations along the profile, although some parts may be misunderstood due the weak signals of some proxies at certain depths, such as between $60 \mathrm{~cm}$ and $100 \mathrm{~cm}$. Overall speaking, these proxies have good consistency.

\subsection{Reconstructing the ultrasonic sounder record}

We then traced the record using the Eagle AWS ultrasonic sounder and compared it with the vertical profile of the Eagle snow pit (Fig. 6). An obviously seasonal variability of snow accumulation (not for precipitation) can be found: the austral summer receives less mass than the other seasons. For example, the summer accumulation was only $\sim 2 \mathrm{~cm}$ of snow (no more than $6 \%$ of the yearly accumulation) during the 2005/06 austral summer.

By reconstructing the snow height change history, we found that accumulations mainly occurred during certain precipitation or snowdrift events, which is illustrated in Fig. 6 and is listed in Table 2. The snow samples in our study were collected on
TCD

1415-1439, 2013

The snowdrift effect on snow deposition

M. Ding et al.

Title Page
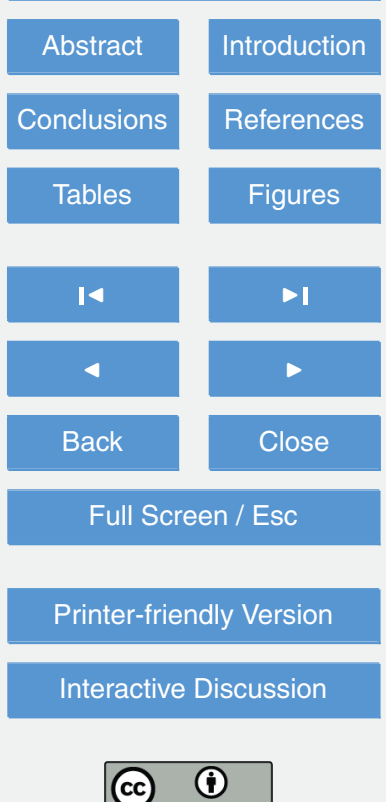
4 January 2008, but the surface snow was deposited during Oct. 2007, which is also implied by the concentrations of $\mathrm{Na}^{+}$and $\mathrm{Cl}^{-}$and the $\delta^{18} \mathrm{O}$ value in Fig. 5. The autumn and winter of 2007 had a stable snow accumulation of $15 \mathrm{~cm}$. Although $7 \mathrm{~cm}$ of snow accumulated, its depositional time was during 6 January and from 24 January 5 to 4 February 2007. The strong wind in $2006\left(4.8 \mathrm{~ms}^{-1}\right.$ in 2006 versus $3.7 \mathrm{~ms}^{-1}$ in 2005 and $4.0 \mathrm{~ms}^{-1}$ in 2007) repeatedly blew away and brought in a snow layer as indicated by the numerous sharp decreases and increases in Fig. 6. However, there was a relatively high snow accumulation. The 2005/06 austral summer received stable precipitation, but most of it drifted away as the result of occasionally strong winds. The 10 spring of 2005 had continual snow accumulation. The snow layer that precipitated from January to July 2005 was lost because of the snowdrift process. Groot Zwaaftink et al. (2013) suggested that the snow might be added to the snow cover permanently only during periods of strong winds, due to the soft snow before would be drifted be strong wind. This assumption in the SNOWPACK model is consistent with our observation.

15 Unfortunately, the Eagle AWS did not continuously record wind speed/direction data because of the extreme environment of the Antarctic inland (Fig. 6). However, we can speculate that wind is the key factor in snowdrift, as many other studies have also noted (e.g. Frezzotti et al., 2004; Scarchilli et al., 2010; Groot Zwaaftink et al., 2013), not only because the process primarily occurs during winter when the surface sublimation is weaker but also because the AWS recorded quick decreases and increases in the snow surface when extremely high winds were detected. Previous studies, such as Winther et al. (2001) and Van de Berg (2006), found that the firn layer can be completely removed by snowdrift erosion and/or sublimation, exposing the glacier ice at the surface in regions with active katabatic winds. Van den Broeke et al. $(2006,2008)$ simulated the snow accumulation distribution under the influence of wind and suggested that the surface sublimation and snowdrift erosion may exceed the solid precipitation flux, resulting in areas with a negative surface mass balance. Frezzotti et al. (2004, 2007) noted that the wind-driven sublimation phenomena determined by the SPWD have a considerable impact on the spatial distribution of snow over in short (tens of metres)

TCD

1415-1439, 2013

The snowdrift effect on snow deposition

M. Ding et al.

Title Page

Abstract Introduction

Conclusions References

Tables Figures

14

$\Delta$

4

Back

$\triangleright$

Close

Full Screen / Esc

Printer-friendly Version

Interactive Discussion 
and medium (kilometre) spatial scales. However, the slope, especially the SPWD in our study area, is low.

\subsection{Estimating the snowdrift process}

As many studies have proved, stable isotopic snow compositions have a linear relation5 ship with the precipitation temperature (e.g. Dansggard 1964; Jouzel et al. 1997). Ding et al. (2010) and Xiao et al. (2012) also provided an empirical formula for $\delta^{18} \mathrm{O} / \delta D$ temperature in this area.

To compare the differences between our dating result from chemical proxies and the real depositional date from the AWS record, we illustrate the variations of both methods along the snow depth in Fig. $7 \mathrm{~b}$. The $\delta^{18} \mathrm{O}$ variation is generally consistent with temperature and has a good correlation in the top $\sim 50 \mathrm{~cm}$. Farther down, however, the dating difference becomes increasingly larger. At $\sim 90 \mathrm{~cm}$, the difference can be as large as 12 months.

Based on the reconstruction of the snow deposition layer shown in Fig. 6 and Table 2, we calculated the real air temperature during the snow deposition events. The $\delta^{18} \mathrm{O}$ temperature relationship is given in Fig. $7 \mathrm{a}$, which shows a linear equation. However, the correlation coefficient is quite low $(R=0.33)$, which suggests that rather the snow layers have been dated precisely by the AWS record, the original precipitation time and locations of these layers (before the snowdrift process) are more important for short-term studies (which cannot be observed currently).

It can be concluded that the snowdrift process has a significant impact on surface snow accumulation. Wind drift, redistribution, and sublimation effects induce the abnormal loss/accumulation of the annual/seasonal layer, disturbing the climate signals. In other words, the credibility of short-term records of the snow profile in windy areas may be limited.

The snowdrift effect on snow deposition

M. Ding et al.

Title Page

Abstract Introduction

Conclusions References

Tables Figures

14 $>1$

4

Back

Close

Full Screen / Esc

Printer-friendly Version

Interactive Discussion 


\section{Conclusions}

By comparing snow chemical/isotopic layers with the highly precise snow accumulation records of the AWS ultrasonic sounder, we uncovered the disturbing effect of the snowdrift process on dating the snow profile. We found a maximum 12 month difference 5 between the $3 \mathrm{yr}$ chemical dating results and the actual deposition time. The variance of the dating depth at the bottom reached up to $27.8 \mathrm{~cm}$, which accounts for $30.6 \%$ of the whole snow pit. Wind-driven processes controlled by wind speed along/against the surface slope not only have a significant effect on surface mass balance evaluation but also on ice core dating.

More importantly, snow layers may be deposited by certain precipitation/snowdrift events and may not indicate a continuous climate record in the Antarctic inland, where the annual precipitation is low and the wind is relatively high. For the coastal area, the high precipitation could smooth/cover the disturbing signal. Furthermore, the snowdrift process is not explicitly included in numerical weather forecasting and general circulation models (e.g. Krinner et al., 2007), although some one-demension models have been well improved (e.g. Fierz and Lehning, 2001; Vionnet et al., 2012).

Dome $\mathrm{A}$ is one of the most attractive positions for recovering the oldest ice cores, as the International Partnerships in Ice Core Sciences noted (IPICS: http://www. pages-igbp.org/ipics/). Dome A is quite close to Eagle and may experience the same atmospheric circumfluence; furthermore, its snow accumulation rate is only $\sim 9 \mathrm{~cm}$ (Hou et al., 2007; Ding et al., 2011). CHINARE started a drilling project in January 2012. One of the greatest challenges is obtaining a reliable record of climate and biogeochemistry. Although we have carried out detailed survey and modelling work (e.g. Hou et al., 2007; Xiao et al., 2008, 2012; Sun et al., 2009; Ding et al., 2010, 2011; Wang et al., 2012), the post-depositional processes should not be neglected or misjudged.
The snowdrift effect on snow deposition

M. Ding et al.

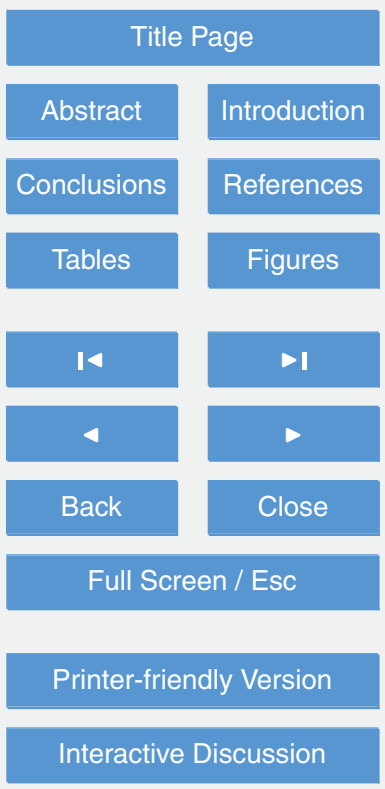


Acknowledgements. This study was funded by the NSFC (41206179; 41121001), the State Oceanic Administration of the People's Republic of China Project on Climate in Polar Regions (CHINARE2012-02-02, CHINARE2012-04-04), and the Post-Doctoral Fund (2011M500462). We are also thankful for the logistical and financial support provided by CHINARE (IC201311).

\section{References}

Allison, I.: Surface climate of the interior of the Lambert Glacier basin, Antarctica, form automatic weather station data, Ann. Glaciol., 27, 515-520, 1998.

Allison, I., Wendler, G., and Radok, U.: Climatology of the East Antarctic ice sheet $\left(100^{\circ} \mathrm{E}\right.$ to $\left.140^{\circ} \mathrm{E}\right)$ derived from automatic weather stations, J. Geophys. Res., 98, 8815-8823, doi:10.1029/93JD00104, 1993.

Anschütz, H., Sinisalo, A., Isaksson, E., McConnell, J. R., Hamran, S. E., Bisiaux, M. M., Pasteris, D., Neumann, T. A., and Winther, J. G.: Variation of accumulation rates over the last eight centuries on the East Antarctic Plateau derived from volcanic signals in ice cores, J. Geophys. Res., 116, D20103, doi:10.1029/2011JD015753, 2011.

15 Bintanja, R.: The contribution of snowdrift sublimation to the surface mass balance of Antarctica, Ann. Glaciol., 27, 251-259, 1998a.

Bintanja, R.: The interaction between drifting snow and atmospheric turbulence, Ann. Glaciol., 26, 167-173, 1998b.

Bintanja, R.: Snowdrift sublimation in a katabatic wind region of the Antarctic Ice Sheet, J. Appl. Meteor., 40, 1952-1966, doi:10.1175/1520-0450(2001)040<1952:SSIAKW>2.0.CO;2, 2001.

Dansgaard, W.: Stable isotopes in precipitation, Tellus, 16, 436-468, 1964.

Ding, M. H., Xiao, C. D., Jin, B., Ren J. W., Qin, D. H., and Sun, W. Z.: Distribution of $\delta^{18} \mathrm{O}$ in surface snow along a transect from Zhongshan Station to Dome A, East Antarctica, Chin. 25 Sci. Bull., 55, 2709-2714, doi:10.1007/s11434-010-3179-3, 2010.

Ding, M. H., Xiao, C. D., Li, Y. S., Ren, J. W., Hou, S. G., Jin, B., and Sun, B.: Spatial variability of surface mass balance along a traverse route from Zhongshan station to Dome A, Antarctica, J. Glaciol., 57, 658-666, doi:10.3189/002214311797409820, 2011.

Eisen, O., Frezzotti, M., Genthon, C., Isaksson, E., Magand, O., van den Broeke, M. R., Dixon, D. A., Ekaykin, A., Holmlund, P., Kameda, T., Karlof, L., Kaspari, S., Lipenkov, V. Y.,

The snowdrift effect on snow deposition

M. Ding et al.

Title Page

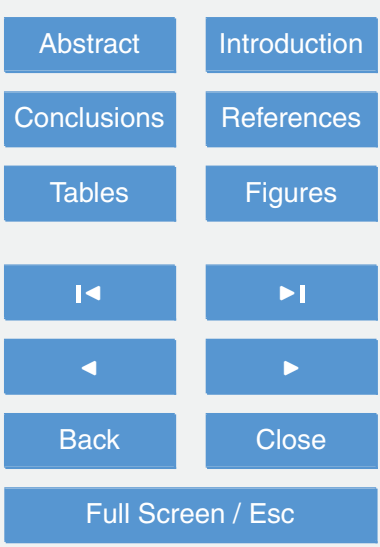

Printer-friendly Version

Interactive Discussion 
Oerter, H., Takahashi, S., and Vaughan, D. G.: Ground-based measurements of spatial and temporal variability of snow accumulation in East Antarctica, Rev. Geophys., 46, RG2001, doi:10.1029/2006RG000218, 2008.

Ekaykin, A. A., Lipenkov, V. Y., Petit, J. R., Johnsen, S., Jouzel, J., and Masson-Delmotte, V.: Insights into hydrological regime of Lake Vostok from differential behavior of deuterium and oxygen-18 in accreted ice, J. Geophys. Res., 115, C05003, doi:10.1029/2009JC005329, 2010.

EPICA Community Members: Eight glacial cycles from an Antarctic ice core, Nature, 429, 623628, doi:10.1038/nature02599, 2004.

10 Fierz, C. and Lehning, M.: Assessment of the microstructure-based snow-cover model SNOWPACK: thermal and mechanical properties, Cold Reg. Sci. Technol., 33, 123-131, doi:10.1016/S0165-232X(01)00033-7, 2001.

Frezzotti, M., Gandolfi, S., and Urbini, S.: Snow megadunes in Antarctica: sedimentary structure and genesis, J. Geophys. Res., 107, 4344, doi:10.1029/2001JD000673, 2002.

15 Frezzotti, M., Pourchet, M., Flora, O., Gandolfi, S., Gay, M., Urbini, S., Vincent, C., Becagli, S., Gragnani, R., Propostio, M., Severi, M., Traversi, R., Udisti, R., and Fily, M.: New estimations of precipitation and surface sublimation in East Antarctica from snow accumulation measurements, Clim. Dynam., 23, 803-813, doi:10.1007/s00382-004-0462-5, 2004.

Frezzotti, M., Urbini, S., Proposito, M., Scarchilli, C., and Gandolfi, S.: Spatial and temporal variability of surface mass balance near Talos Dome, East Antarctica, J. Geophys. Res., 112, F02032, doi:10.1029/2006JF000638, 2007.

Gallée, H.: A simulation of blowing snow over the Antarctic ice sheet, Ann. Glaciol., 26, 203205, 1998

Gallée, H., Guyomarch, G., and Brun, E.: Impact of snow drift on the Antarctic Ice Sheet surface mass balance: possible sensitivity to snow-surface properties, Bound.-Lay. Meteorol., 99, 119, 2001.

Gallée, H., Trouvilliez, A., Agosta, C., Genthon, C., Favier, V., and Naalm-bouvet, F.: Transport of snow by wind: a comparison between observations in Adelie Land, Antarctica, and simulations made with the regional climate model MAR, Bound.-Lay. Meteorol., 146, 133-147, 30 doi:10.1007/s10546-012-9764-z, 2013.

Goodwin, I. D.: Snow-accumulation variability from seasonal surface observations and firn-core stratigraphy, eastern Wilkes Land, Antarctica, J. Glaciol., 37, 383-387, 1991. 
Gow, A. J.: On the rates of growth of grains and crystals in South Pole firn, J. Glaciol., 8, 241-252, 1969.

Groot Zwaaftink, C. D., Cagnati, A., Crepaz, A., Fierz, C., Macelloni, G., Valt, M., and Lehning, M.: Event-driven deposition of snow on the Antarctic Plateau: analyzing field measurements with SNOWPACK, The Cryosphere, 7, 333-347, doi:10.5194/tc-7-333-2013, 2013.

Hou, S., Li, Y., Xiao, C., and Ren, J.: Recent accumulation rate at Dome A, Antarctica, Chin. Sci. Bull., 52, 428-431, 2007.

Jouzel, J., Alley, R. B., and Cuffey, K. M.: Validity of the temperature reconstruction from water isotopes in ice cores, J. Geophys. Res., 102, 26471-26487, 1997.

10 Jiang, S., Cole-Dai, J. H., Li, Y., Ferris, D. G., Ma, H., An, C., Shi, G., and Sun, B.: A detailed 2840 year record of explosive volcanism in a shallow ice core from Dome A, East Antarctica, J. Glaciol., 58, 65-75, doi:10.3189/2012JoG11J138, 2012.

Krinner, G., Magand, O., Simmonds, I., Genthon, C., and Dufresne, J. L.: Simulated Antarctic precipitation and surface mass balance at the end of the twentieth and twenty-first centuries,

15 Clim. Dynam., 28, 215-230, doi:10.1007/s00382-006-0177-x, 2007.

Legrand, M. and Mayewski, P.: Glaciochemistry of polar ice cores: a review, Rev. Geophys., 35, 219-243, 1997.

Li, C. J., Xiao, C. D., Hou, S. G., Ren, J. W., Ding, M. H., and Guo, R.: Dating a $109.9 \mathrm{~m}$ ice core from Dome A (East Antarctica) with volcanic records and a firn densification model, Sci.

20 China Earth Sci., 55, 1280-1288, doi:10.1007/s11430-012-4393-4, 2012.

Ma, Y. F., Bian, L. G., Xiao, C. D., Allison, I., and Zhou, X. J.: Near surface climate of the traverse route from Zhongshan Station to Dome A, East Antarctica, Antar. Sci., 22, 443-459, doi:10.1017/S0954102010000209, 2010.

Mann, G. W., Anderson, P. S., and Mobbs, S. D.: Profile measurements of blowing snow at Halley, Antarctica, J. Geophys. Res., 105, 24491-24508, 2000.

McConnell, J. R., Bales, R. C., and Davis, D. R.: Recent intra-annual snow accumulation at South Pole: implications for ice core interpretation, J. Geophys. Res., 102, 21947-21954, 1997.

Paterson, W. S. B.: The Physics of Glaciers, Third Edition, Pergamon, Oxford, 480 pp., 1994.

30 Petit, J. R., Jouzel, J., Pourchet, M., and Merlivat, L.: A detailed study of snow accumulation and stable isotope content in Dome C (Antarctica), J. Geophys. Res.-Oc. Atm., 87, 4301-4308, 1982.

The snowdrift effect on snow deposition

M. Ding et al.

Title Page

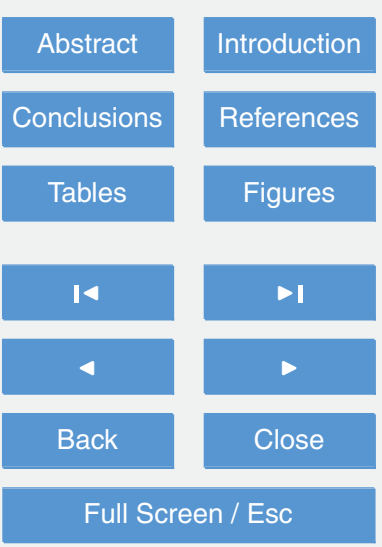

Printer-friendly Version

Interactive Discussion 
Pomeroy, J. W. and Jones, H. G.: Wind-blown snow: sublimation, transport and changes to polar snow, in: Chemical Exchange Between the Atmosphere and Polar Snow, edited by: Wolff, E. W. and Bales, R. C., NATO ASI Series, 143, Springer Verlag, Berlin \& Heidelberg, 453-489, 1996.

5 Qin, D. H.: Antarctic Glaciology, Science Press, Beijing, 239 pp., ISBN: 7-03-009092-6, 2001.

Ren, J. W., Xiao, C. D., Hou, S. G., Li, Y. S., and Sun, B.: New focuses of polar ice-core study: NEEM and Dome A, Chin. Sci. Bull., 54, 1009-1011, doi:10.1007/s11434-009-0012-y, 2008.

Rignot, E., Bamber, J., van den Broeke, M. R., Davis, C., Li, Y., van de Berg, W. J., and Meijgaard, E. V.: Recent Antarctic ice mass loss from radar interferometry and regional climate 10 modelling, Nat. Geosci., 1, 106-110, doi:10.1038/ngeo102, 2008.

Scarchilli, C., Frezzotti, M., Didonfrancesco, G., Valt, M., Urbini, S., De Silvestri, L., Dolci, S., lacarino, A., and Grigioni, P.: The impact of precipitation and sublimation processes on snow accumulation: preliminary results, Terra Antarct. Publ., 14, 47-50, 2008.

Scarchilli, C., Frezzotti, M., Grigioni, P., De Silvestri, L., Agnoletto, L., and Dolci, S.: Extraor15 dinary blowing snow transport events in East Antarctica, Clim. Dynam., 34, 1195-1206, doi:10.1007/s00382-009-0601-0, 2010.

Scarchilli, C., Frezzotti, M., and Ruti, P. M.: Snow precipitation at four ice core sites in East Antarctica: provenance, seasonality and blocking factors, Clim. Dynam., 37, 2107-2125, doi:10.1007/s00382-010-0946-4, 2011.

20 Smith, M. C.: The role of atmospheric processes in the Antarctic ice mass balance, Ph.D. Thesis, University of Leeds, Leeds, UK, 220 pp., 1995.

Stearns, C. R. and Weidner, G. A.: Sensible and latent heat flux estimates in Antarctic, in: Antarctic Meteorology and Climatology: Studies Based on Automatic Weather Stations, Antarctic Res. Ser., vol. 61, edited by: Bromwich, D. H. and Stearns, C. R., AGU, Washington, D. C., 109-138, 1993.

Sun, B., Siegert, M. J., Mudd, S. M., Sugden, D. E., Fujita, S., Cui, X., Jiang, Y., Tang, X., and $\mathrm{Li}, \mathrm{Y}$.: The Gamburtsev Mountains and the origin and early evolution of the Antarctic ice sheet, Nature, 459, 690-693, 2009.

Van de Berg, W. J., van den Broeke, M. R., Reijmer, C. H., and van Meijgaard, E.: Reassess30 ment of the Antarctic surface mass balance using calibrated output of a regional atmospheric climate model, J. Geophys. Res., 111, D11104, doi:10.1029/2005JD006495, 2006.

The snowdrift effect on snow deposition

M. Ding et al.

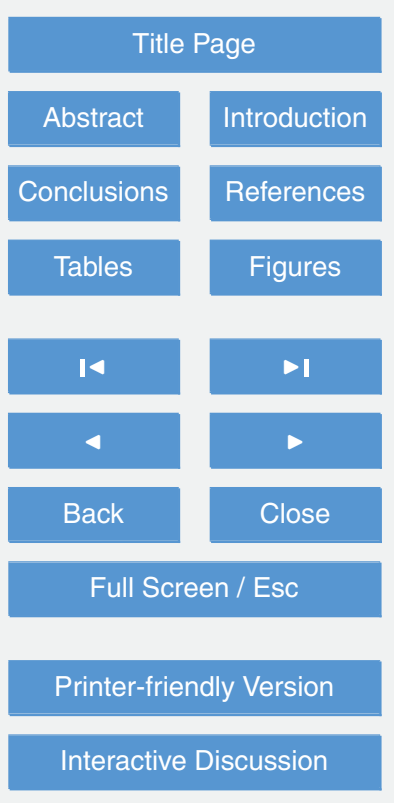


Van den Broeke, M. R., Reijmer, C. H., and van de Wal, R. S. W.: A study of the surface mass balance in Dronning Maud Land, Antarctica, using automatic weather stations, J. Glaciol., 50, 565-582, 2004.

Van den Broeke, M. R., van de Berg, W. J., van Meijgaard, E., and Reijmer, C.: Identification of

5 Antarctic ablation areas using a regional atmospheric climate model, J. Geophys. Res., 111, D18110, doi:10.1029/2006JD007127, 2006.

Van den Broeke, M. R., van de Berg, W. G., and van Meijgaard, E.: Firn depth correction along the Antarctic grounding line, Antar. Sci., 20, 513-517, doi:10.1017/S095410200800148X, 2008.

10 Vionnet, V., Brun, E., Morin, S., Boone, A., Faroux, S., Le Moigne, P., Martin, E., and Willemet, J.-M.: The detailed snowpack scheme Crocus and its implementation in SURFEX v7.2, Geosci. Model Dev., 5, 773-791, doi:10.5194/gmd-5-773-2012, 2012.

Wang, Y., Sodemann, H., Hou, S., Masson-Delmotte, V., Jouzel, J., and Pang, H.: Snow accumulation and its moisture origin over Dome Argus, Antarctica, Clim. Dynam., 40, 731-742, doi:10.1007/s00382-012-1398-9, 2013.

Watanabe, O.: Distribution of surface features of snow cover in Mizuho Plateau, Mem. Natl. Inst. Pol. Res., 7, 154-181, 1978.

Williams, C. N., Basist, A., Peterson, T. C., and Grody, N.: Calibration and verification of land surface temperature anomalies derived from the SSM/I, B. Am. Meteorol. Soc., 81, 21412156, 2000.

Winther, J. G., Jespersen, M. N., and Liston, G. E.: Blue-ice areas in Antarctica derived from NOAA AVHRR satellite data, J. Glaciol., 47, 325-334, 2001.

Wu, G. J., Yao, T. D., Thompson, L. G., and Li, Z. Q.: Microparticle record in the Guliya ice core and its comparison with polar records since the last interglacial, Chin. Sci. Bull., 49, 607-611, doi:10.1360/03wd0419, 2004.

Xiao, C., Li, Y., Allison, I., Hou, S., Dreyfus, G., Barnola, J. M., Ren, J., Bian, L., Zhang, S., and Kameda, T.: Surface characteristics at Dome A, Antarctica: first measurements and a guide to future ice-coring sites, Ann. Glaciol., 48, 82-87, 2008.

Xiao, C., Ding, M., Masson-Delmotte, V., Zhang, R., Jin, B., Ren, J., Li, C., Werner, M., Wang, Y., Cui, X., and Wang, X.: Stable isotopes in surface snow along a traverse route from Zhongshan station to Dome A, East Antarctica, Clim. Dynam., doi:10.1007/s00382-012-1580-0, 2012.

The snowdrift effect on snow deposition

M. Ding et al.

Title Page

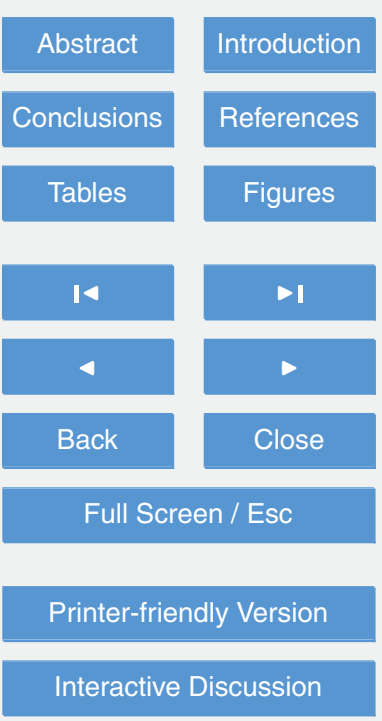

Interactive Discussion 
Zhou, M., Zhang, Z., Zhong, S., Lenschow, D., Hsu, H. M., Sun, B., Gao, Z., Li, S., Bian, X., and Yu, L.: Observations of near-surface wind and temperature structures and their variations with topography and latitude in East Antarctica, J. Geophys. Res., 114, D17115, doi:10.1029/2008JD011611, 2009.

The snowdrift effect on snow deposition

M. Ding et al.

Title Page

Full Screen / Esc 
Table 1. Specifications of the Eagle AWS.

\begin{tabular}{llll}
\hline Sensor & Type & Range & Accuracy \\
\hline Air thermometer & FS23D thermistor & $-85-65^{\circ} \mathrm{C}$ & $0.02^{\circ} \mathrm{C}$ \\
Hygrometer & Vaisala HMP45D & $0-100 \%$ & $2 \%(\mathrm{RH}<90 \%)$ \\
& & & $3 \%(\mathrm{RH}>90 \%)$ \\
& Young P/L cup anemometer & $0-51.1 \mathrm{~m} \mathrm{~s}^{-1}$ & $0.1 \mathrm{~m} \mathrm{~s}^{-1}$ \\
Anemometer & Aanderra 3590 vane & $0-360^{\circ}$ & $6^{\circ}$ \\
Anemoscope & Campbell Scientific SR50-45 & $0.5-10 \mathrm{~m}$ & $0.01 \mathrm{~m}$ \\
Ultrasonic sounder & Middleton EP08 & $0-204.8 \mathrm{MJ}$ & $0.1 \mathrm{MJ} \mathrm{m}^{-2}$ \\
Radiometer & Paroscientific Digiquartz 6501A & & $0.1 \mathrm{hPa}$ \\
Barometer & & $-85-65^{\circ} \mathrm{C}$ & $0.02^{\circ} \mathrm{C}$ \\
Subsurface thermometer & FS23D thermistor & & \\
\hline
\end{tabular}

The snowdrift effect on snow deposition

M. Ding et al.

Title Page

Abstract

Introduction

Conclusions

References

Tables

Figures

14

$\rightarrow \mathbf{I}$

4

Back

Close

Full Screen / Esc

Printer-friendly Version

Interactive Discussion 
Table 2. Summary of snow events at the Eagle AWS site based on the record of the ultrasonic sounder.

\begin{tabular}{|c|c|c|}
\hline $\begin{array}{l}\text { Deposition time of } \\
\text { snow layer }\end{array}$ & $\begin{array}{l}\text { Thickness of } \\
\text { snow layer }(\mathrm{cm})\end{array}$ & $\begin{array}{l}\text { Cumulative height of } \\
\text { snow surface }(\mathrm{cm})\end{array}$ \\
\hline 20-30 Jul 2005 & 3 & 3 \\
\hline 10 Aug 2005 & 3 & 6 \\
\hline 10-20 Sep 2005 & 5 & 11 \\
\hline 20 Sep-25 Oct 2005 & 6 & 17 \\
\hline 10-20 Dec 2005 & 2 & 19 \\
\hline 1-10 Mar 2006 & 8 & 27 \\
\hline 10-20 Apr 2006 & 2 & 29 \\
\hline 20-30 Apr 2006 & 1 & 30 \\
\hline Jun-Aug 2006 & 20 & 50 \\
\hline 1-10 Sep 2006 & 2 & 52 \\
\hline 14 Sep-2 Oct 2006 & 7 & 59 \\
\hline 1-10 Nov 2006 & 3 & 62 \\
\hline 1-10 Jan 2007 & 7 & 69 \\
\hline 1-10 Feb 2007 & 3 & 72 \\
\hline 10-20 Mar 2007 & 3 & 75 \\
\hline 20-30 Apr 2007 & 3 & 78 \\
\hline 20 May-10 Jul 2007 & 6 & 84 \\
\hline 20-30 Nov 2007 & 4 & 88 \\
\hline
\end{tabular}

7, 1415-1439, 2013

The snowdrift effect on snow deposition

M. Ding et al.

Title Page

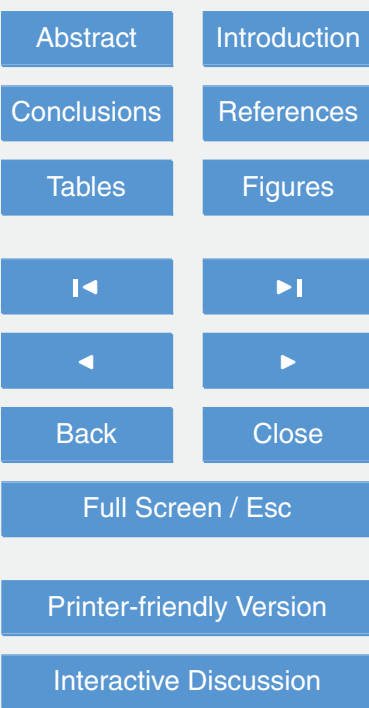




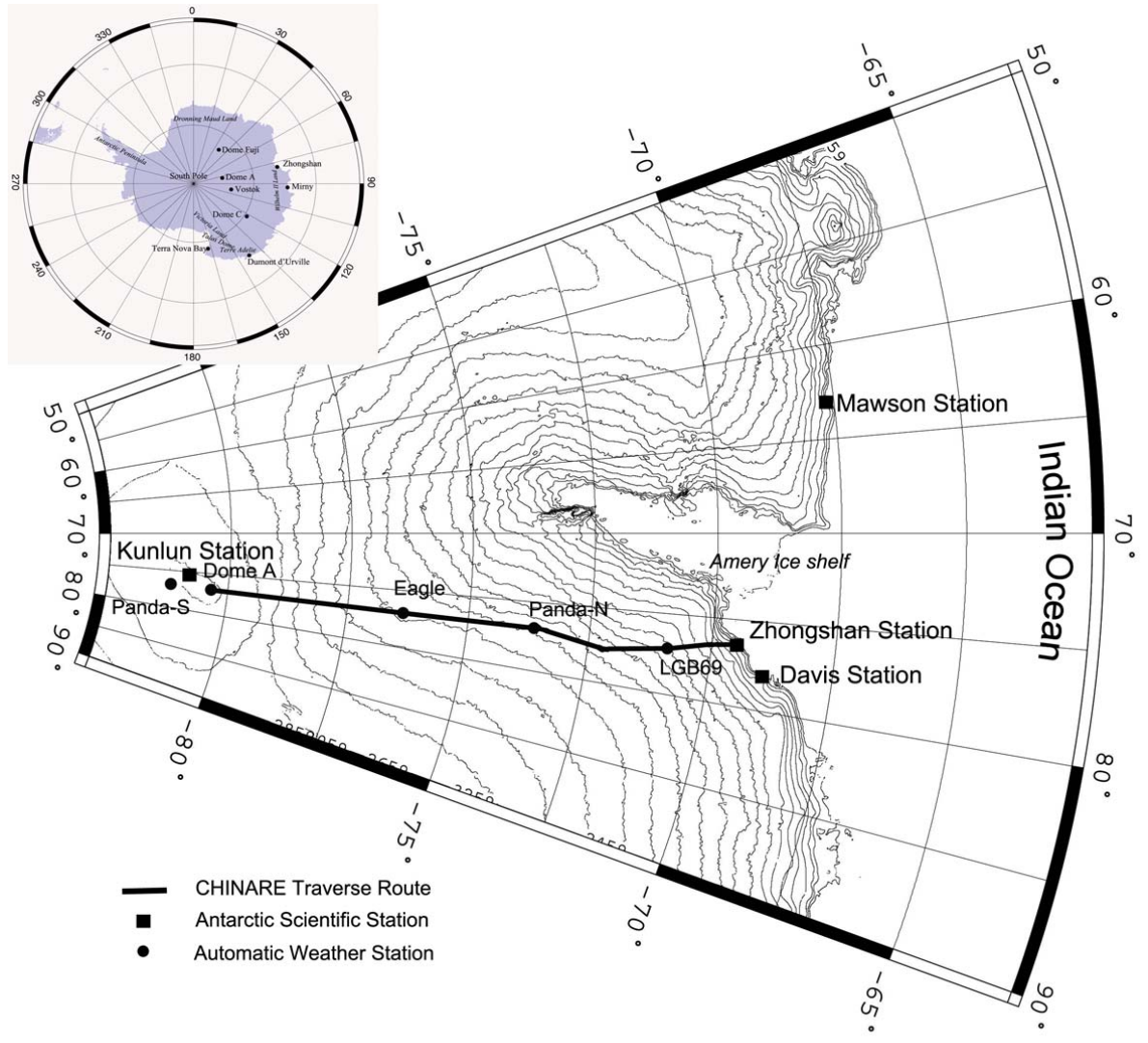

\section{TCD}

7, 1415-1439, 2013

The snowdrift effect on snow deposition

M. Ding et al.

Title Page

Abstract

Introduction

Conclusions

References

Tables

Figures

14

$>1$

4

Back

Full Screen / Esc

Printer-friendly Version

Interactive Discussion 


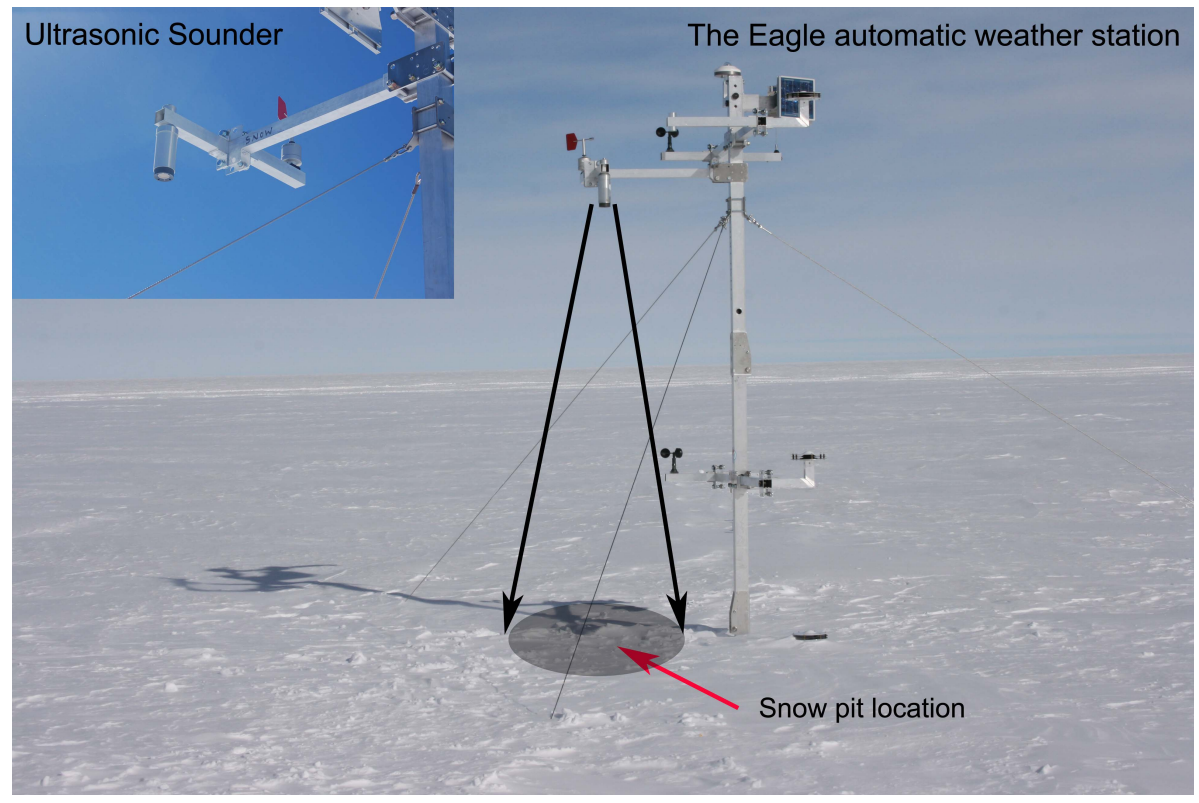

\section{TCD}

7, 1415-1439, 2013

The snowdrift effect on snow deposition

M. Ding et al.

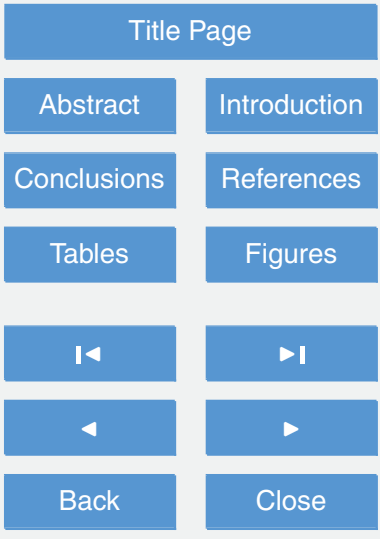

Full Screen / Esc

Fig. 2. The Eagle AWS and snow pit diagram.

Printer-friendly Version

Interactive Discussion

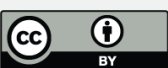




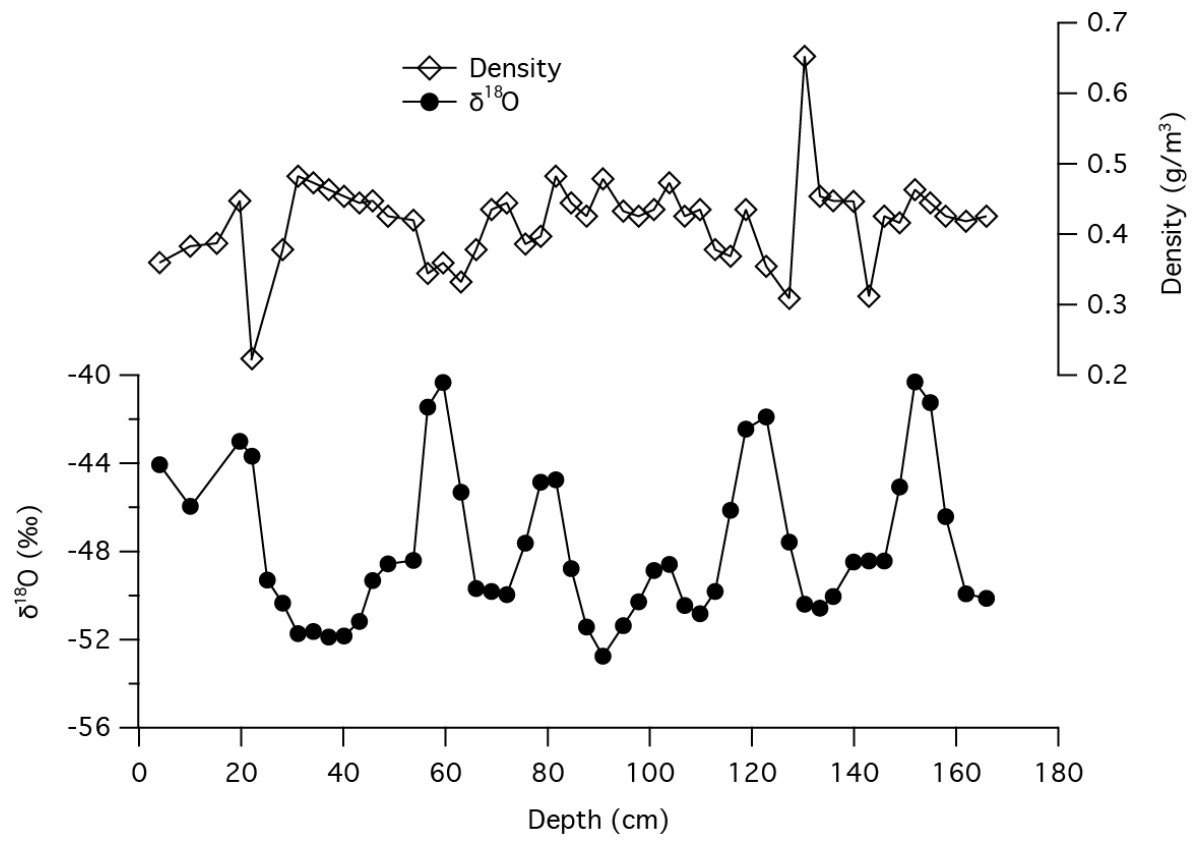

Fig. 3. The variations of $\delta^{18} \mathrm{O}$ values and snow density along the Eagle snow pit profile.

\section{TCD}

7, 1415-1439, 2013

The snowdrift effect on snow deposition

M. Ding et al.

Title Page

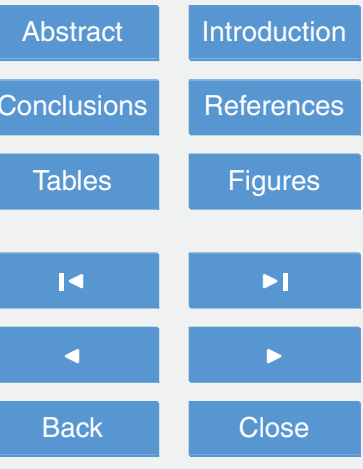

Full Screen / Esc

Printer-friendly Version

Interactive Discussion 

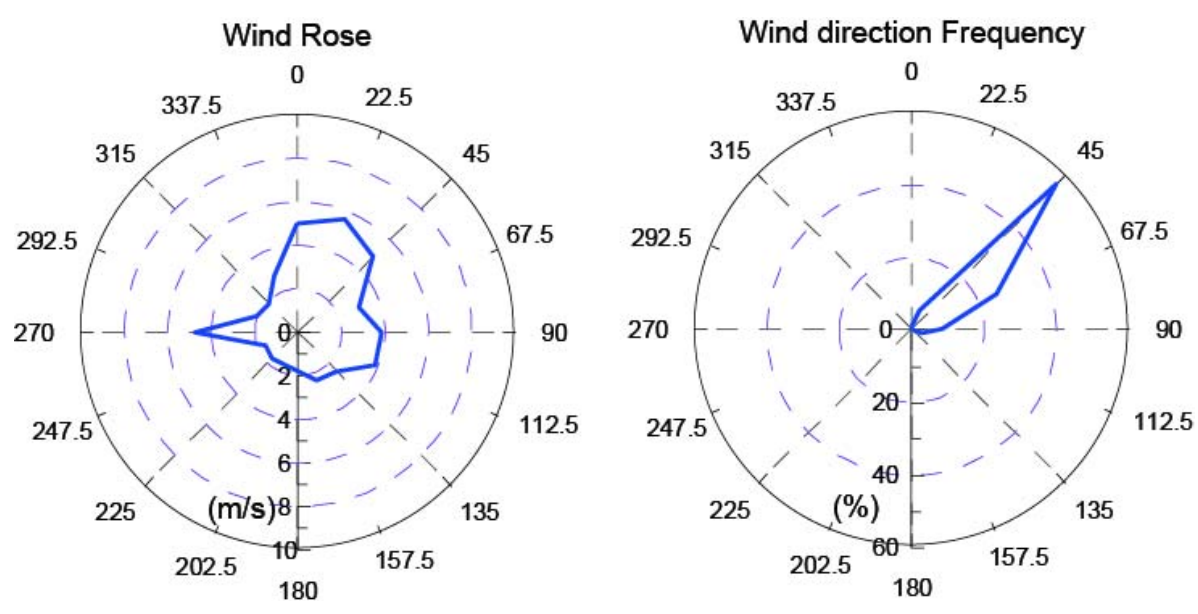

Fig. 4. Wind speed/direction and wind direction frequency analyses for the Eagle AWS during January 2005-January 2008.

\section{TCD}

$7,1415-1439,2013$

The snowdrift effect on snow deposition

M. Ding et al.

Title Page

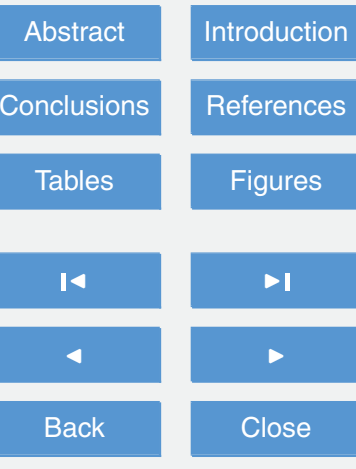

Full Screen / Esc

Printer-friendly Version

Interactive Discussion 


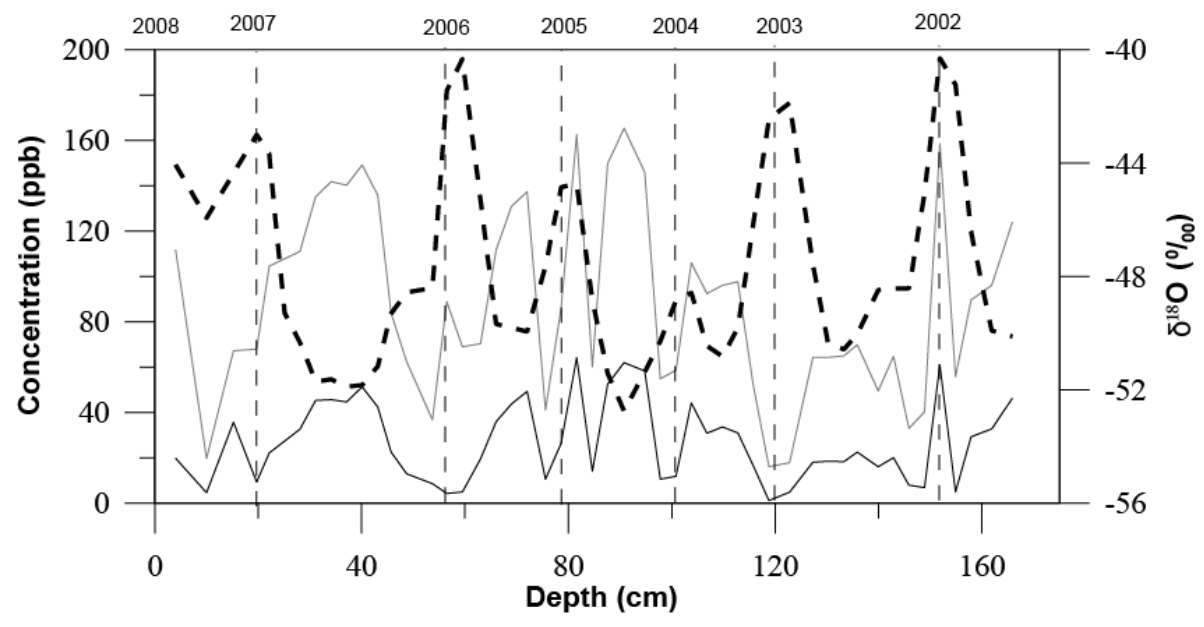

Fig. 5. The dating results of the Eagle pit by marine aerosol and $\delta^{18} \mathrm{O}$ cycles (the solid black, solid grey, and dotted black lines represent $\mathrm{Na}^{+}, \mathrm{Cl}^{-}$, and $\delta^{18} \mathrm{O}$, respectively).

\section{TCD}

$7,1415-1439,2013$

The snowdrift effect on snow deposition

M. Ding et al.

Title Page

Abstract

Conclusions

Tables

14

4

Back

Full Screen / Esc

Printer-friendly Version

Interactive Discussion 


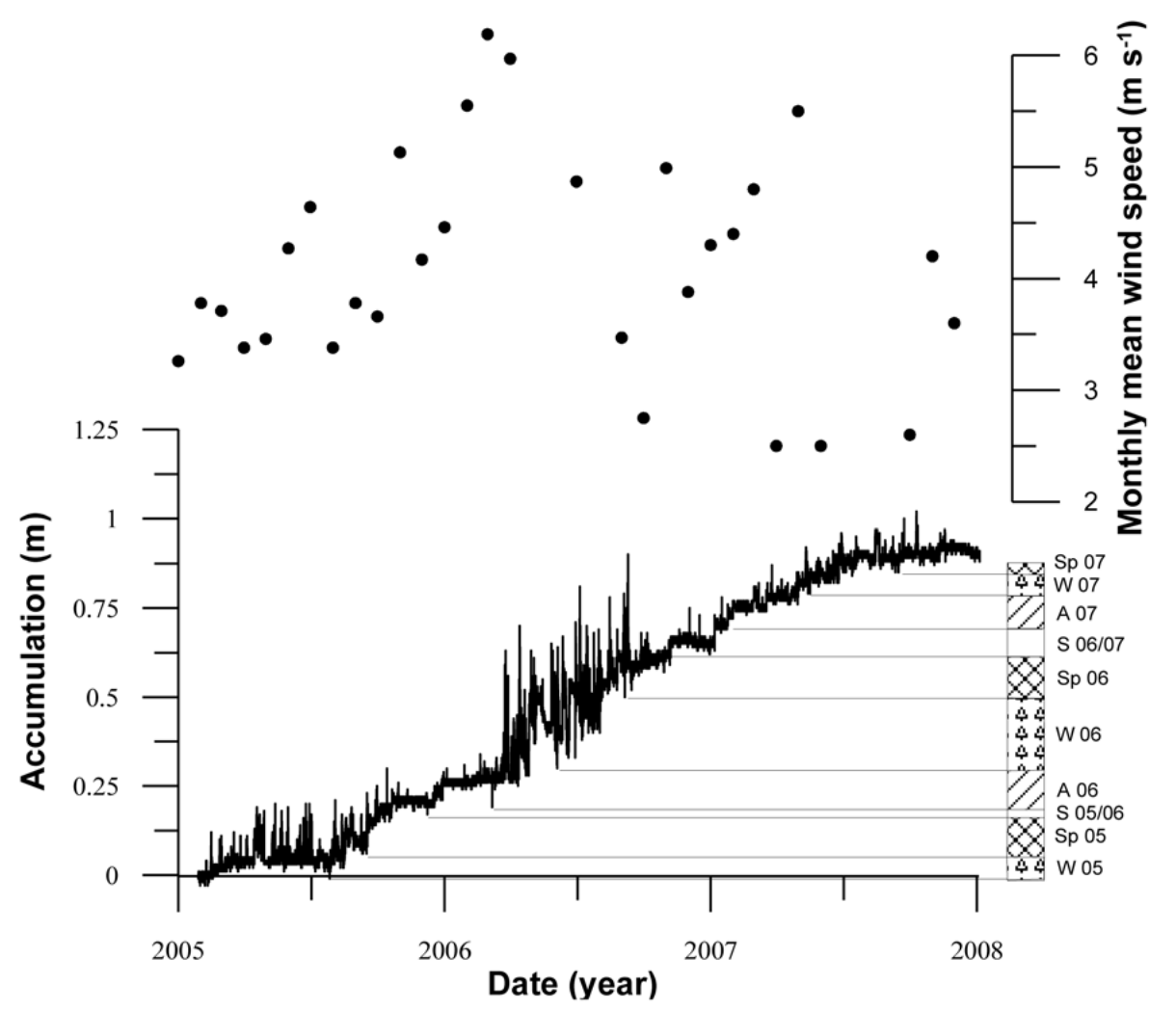

Fig. 6. Dating of the snow profile by the record of the ultrasonic sounder (bottom) and the monthly mean wind speed during January 2005 and December 2007 (top) at the Eagle AWS (Sp: spring; S: austral summer; A: autumn; W: winter).
TCD

7, 1415-1439, 2013

The snowdrift effect on snow deposition

M. Ding et al.

Title Page

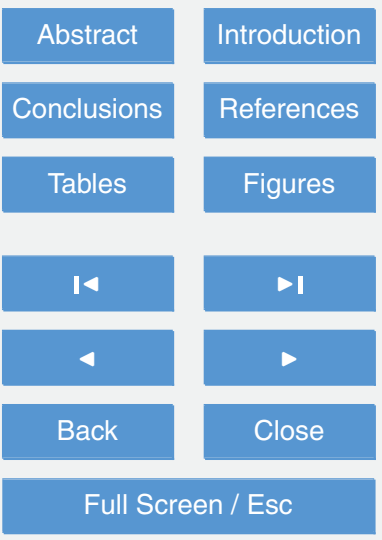

Printer-friendly Version

Interactive Discussion 

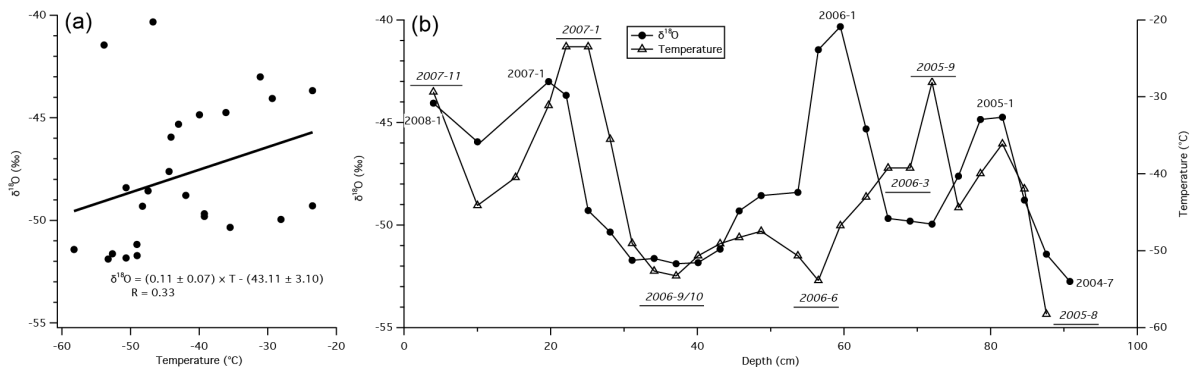

Fig. 7. Comparison of $\delta^{18} \mathrm{O}$ records from the snow pit vs. air temperature records from the AWS. (a) Correlation analysis between $\delta^{18} \mathrm{O}$ and air temperature. (b) The difference in the dating depths between the $\delta^{18} \mathrm{O}$ method and the ultrasonic sounder records. The italic dates in (b) represent the real date of the depth; the other dates represent the dating results from the $\delta^{18} \mathrm{O}$ method.

\section{TCD}

$7,1415-1439,2013$

The snowdrift effect on snow deposition

M. Ding et al.

Title Page
Abstract

Conclusions

Tables

14

4

Back
Introduction

References

Figures

$>1$

$>$

Close
Full Screen / Esc

Printer-friendly Version

Interactive Discussion 